\title{
Differentiating Medical Malpractice From Medical Complications
}

\author{
HRVOJE VOJKOVIĆ
}

\begin{abstract}
Determining the notion of medical complications leads to differentiating in particular complications that are the unwanted result of a medical procedure. In particular, the factual and medical cause is to be sought in the nature of the damage and the circumstances of its onset through no fault of the physician, from those complications that are the undesired consequence of unprofessional medical care. In the latter case law theory and practice recognizes a situation that is standing in a causal relationship with legally relevant damages and which makes the medical practitioner civilly liable for harmful consequences. Therefore, complications in medical treatment procedures are a harmful event occurring in the medical treatment of a patient which is caused by the undesired and unavoidable course of illness/injury or the patient's overall state of health, despite the fact that the medical treatment was performed completely lege artis, and in accordance with moral and ethical principles of the healthcare profession and standards in modern medical science.
\end{abstract}

Keywords: - Medical Malpractice - Medical Complication - Civil Liability of Medical Practitioners $\bullet$ Medical Law $\bullet$ Civil Law $\bullet$

CorResPondence AdDress: Hrvoje Vojkovic, PhD, Senior Assistant, University Sjever, 104 brigade 3, Varaždin, Croatia; director/owner Naša Farma d.o.o., Ravnica 8, Oprtalj, Croatia, email: hvojkovic@gmail.com. 


\section{$1 \quad$ Civil Liability of Medical Practitioners}

\section{Introductory Notes}

Given that medicine is not an exact science, providing medical treatment always entails a certain degree of risk that can unfortunately result in harmful, undesired consequences. These harmful consequences can stem from either medical errors by a physician or the physician's failure to honor the patient's right to partake in his or her medical decisions. Literature points out that over the past decade, the phenomenon of denunciations and/or litigation, judicial and extrajudicial, for cases of presumed "malpractice or bad healthcare" has recorded an increase ranging from minimum value of double-digit percentage ( $>50$ percent) (Ferrara, Boscolo-Berto \& Viel, 2013: 4). Attention is drawn to the fact that according to the Special Eurobarometer on Medical Errors, about 80 percent of EU citizens perceive medical errors as a major issue and approximately 50 percent believe they will be personally involved in a case of medical malpractice (European commission, 2006).

Likewise, research at two healthcare institutions in the USA has shown that up to 3.9 percent of patients suffer harm to their health as a consequence of medical treatment, whereas in Denmark this percentage is as high as 9 percent; in France 8.9 percent; and, in Great Britain 11 percent. The fact that medical malpractice is the eighth most common cause of death in the USA (Škavić \& Zečević, 2008: 23) points to the seriousness of the problem. Relevant international literature suggests a trend of "increasing inclination towards seeking damages". Namely, patients are increasingly expressing objections to the work of physicians while serious breaches of rules in the medical profession are being uncovered which should have been identified and eliminated earlier through internal controls. In general, literature does in essence suggest a low level of patient trust in physicians (Budak, 2014: 275-276). In the USA and EU (especially some countries such as Italy), medical liability is, in itself, a booming industry. The USA, for example, produces a cumulative annual expenditure (direct and indirect costs) for various reasons amounting to \$17-19 billion annually, according to the American Institute of Medicine. According to another study, consequences of medical malpractice in the USA have exceeded damages caused by traffic accidents, annually incurring harm to more than 1.5 million American patients (Arlen, 2013: 59). In Great Britain, there were approximately 500 malpractice tort claims asserted in 1978. That number mushroomed to approximately 7,000 cases in the period from 1990-1991, and the trend of increasing numbers of malpractice cases has continued (Tarantino, Giai Via, Macri, Eramo, Marino, \& Marsella, 2013). Likewise, similar trends could be found in Italy, where there has been a 50 percent increase in the number of medical malpractice cases filed in the period from 19801986, with an additional increase of 90 percent in 1987 (Traina, 2009). In Italy, about 15,000 tort claims are initiated annually due to damages allegedly caused by medical malpractice. As a result, healthcare institutions pay out about 10 billion euros per annum in compensation to patients (Traina, 2009: 1). 
The recent statistics show that Europeans have become increasingly aware of their medical rights and legal recourse to pursue claims for compensation against healthcare professionals. In turn, the increase in the assertion of claims has resulted in a proportional increase in the cost of the coverage of claims, estimated to be in excess of 200 percent by the European Hospital and Healthcare Federation in the period of 2005-2010. These costs, distributed across the European population, fluctuate between 9 - 15 Euro per capita (Ferrara, Boscolo-Berto \& Viel, 2013: 5).

Legal theory states that in determining the substance of standards within the medical profession it is necessary to determine the established and recognized rules of the medical profession which will indicate a possible breach of the duty to exercise due care (Petrić, 2005: 123) and hence medical malpractice. Namely, a breach of the duty to exercise due care undoubtedly indicates the existence of fault as a subjective element of unlawfulness and the presumption of the existence of tort liability which is required in most legal systems. In short, medical malpractice occurs when the actions by the physician when caring for a patient fail to comply with the verified standards of modern medical science, including its moral and ethical principles, and which results in an infringement to the patient's health, life and right of personality. However, medical personnel will not face civil liability for medical treatment they render simply because that medical treatment, which fully comports with the recognized standard of care, results in a less than optimal outcome or which subsequently leads to unavoidable medical complications. Namely, it is well-known that every medical procedure carries with it certain known, inherent risks as well as other risks that, based on current medical science, are not precisely known yet nevertheless exist. In consenting to a medical procedure the patient assumes these risks.

Importantly, Croatian legislation and the respective legal system by disposition, makes no distinction between medical malpractice and complications arising from medical treatment (medical complications) and does not articulate specific criteria for making legal distinctions between these two harmful events. Given the apparent similarity between these two situations, i.e., medical malpractice and medical complications, especially in terms of unfavourable outcomes of medical treatment, and their quite different civil law implications, it is important to differentiate the terms medical malpractice and medical complications. Accordingly, medical malpractice and medical complications may be distinguished with regard to criteria of difference of causes. Contrary to the term "medical malpractice", the term "complications" in medical treatment refers to a medical procedure resulting in an undesired result despite the proper and timely performance of the procedure including the appropriate use of equipment and other means (medicines, chemical substances and the like), and coinciding with an optimal approach to the work carried out. Therefore, a complication in a medical procedure is a harmful event that occurs due to treatment undertaken by the patient, and where the physician's suboptimal actions are not the underlying cause of the medical complications. In other words, there is no medical malpractice in situations where there is no causal link between the physician's actions and the onset of the harmful event for which guilt may be attributed, and the onset of the harm represents an incident which excludes civil liability. 
The main research subject addressed by this paper is how best to differentiate medical malpractice from medical complications in theory and practice with respect to the treatment of medical malpractice in tort liability. We have employed scientific methods to develop relevant solutions in Croatian and comparative law and practice, with distinctive elements for differentiating, in casu particulari ad curiam, the terms 'medical complications' from legally relevant medical malpractice that leads to tort liability. The aim of this paper was to investigate and define the essential elements that constitute a physician's breach of medical standards and which in turn can result in civil liability, and to draw a distinction between medical malpractice and mere medical complications which should not result in physician legal culpability.

In conducting our research for this paper we have employed both the comparative and inductive methods. In the framework of a comparative analysis of different normative arrangements for the institution of tort liability in medical malpractice, the relevant points in legal theory have been elaborated, with an emphasis placed on comparatively investigating legal precedence. The inductive method used in researching civil law is applied such that every particular quaestio iuris is analysed through a prism of associated legal provisions that are regulated. Namely, the analyses have been done on the basis of relevant legal literature addressing the respective subject, via the respective legal precedence from which final conclusions can be drawn.

This paper will focus on a comparative analysis between healthcare systems and regulations in the US, EU and Croatia. We will examine the general framework of tort liability for physicians in those countries, and will elaborate upon the development of the concept of medical malpractice. A special emphasis will be placed on the issue of distinguishing medical malpractice from medical treatment complications, including an overview of relevant best practices and established criteria for differentiating medical malpractice from medical complications. We also will examine an illustrative presentation of typical cases from Croatian legal precedence (case study).

\subsection{An Overview of Certain Economic Effects of Tort Liability Due to Breaches of Medical Standards}

Literature from the fields of economics, medicine and law that we analyed in preparing this paper confirms the trend that there has been an increase in the number of tort claims initiated against physicians for monetary compensation due to their alleged breach of medical standards. Data cited for the USA indicates a growth in total costs incurred resulting from medical malpractice. The average expense of defending a physician against a medical liability claim in 2010 was $\$ 47,158.00$, an increase of 62.7 percent since 2001. In 2010, 63.7 percent of tort claims against physicians were legally resolved (either dropped, withdrawn, or dismissed without any payment) in favor of the defendant. Each of those ultimately unsuccessful claims still cost an average of $\$ 26,851.00$ to defend. However, when successful, the claimant received a substantial award. The average medical liability payment to the successsful claimant in 2010 amounted to $\$ 331,947.00$, which represents an increase of 11.5 percent since 2001. The proportion of medical liability insurance policies carried by physicians with policy limits exceeding $\$ 1$ million increased from 28 percent to 41 percent in the same period (Lewis, 2012: 1-2). Furthermore, American economic theory points out (Arlen, 
2010) that between 4-18 percent of patients suffer the adverse health and economic consequences of medical malpractice. Nonetheless, as a rule, only a relatively small number of medical malpractice victims assert tort claims for compensation for damages. However, according to one study, financial expenditures stemming from the actions of physicians classified as against the law (contra legem artis) lead to direct increases in hospital expenditures ranging from $\$ 1,246.00$ to $\$ 4,769.00$ per year per patient admission, depending on the type of healthcare institution and specific medical treatment conducted there. All in all, total yearly expenditures across various institutions, and which are per directum et indirectum caused by the actions of physicians and other healthcare personnel contrary to the rules of the medical profession, are estimated to be a whopping $\$ 17-\$ 29$ billion annually, according to the Institute of Medicine (Arlen, 2010).

A similar situation exists in Italy. The highest percentage of tort claims are made against healthcare professionals that practice in the field of orthopaedic surgery and traumatology. Further, throughout the entire EU the greatest number of criminal proceedings are initiated against healthcare personnel practicing in those two fields. Statistics suggest that a physician with 20 years of practice has an 80 percent chance of being subjected to a tort claim for alleged medical practice but also an 80 percent chance that the claim will be rejected in favour of the healthcare professional (Fattorini, Peretti, Bergamini \& Valentini, 2007). According to another Italian study (Tarantino et al., 2013), civil lawsuits for damages were initiated against 243 surgeons. Liability was established in 75 percent of those cases. 61 percent of the cases where liability was established related to elective orthopaedic surgery. Surgical teams were sued in only 30 cases with tort liability ascertained and compensation for damages determined in 22 of those cases. The total amounted awarded for remediation of damage amounted to $€ 12,350,000.00$. Interestingly, the courts make a distinction between emergency and elective surgery, where damages are awarded to the average amount of $€ 896,989.00$ when involving elective surgery compared to $€ 297,921.00$ when the death of a patient is caused during emergency surgical procedures (i.e. traumatology).

A recent comparative analysis of the quality of healthcare protection in Croatia and other EU countries (EHCI index) has shown that at times, regardless of public criticism of the public healthcare system in Croatia, patients have expressed overall satisfaction with the work of medical personnel. This conclusion is supported by research conducted in 2010 on 3,000 respondents by the Institute of Economics in Zagreb and UNODC. The research showed that around 40 percent of citizens consider the quality of services provided by physicians and medical nurses in Croatia are "very good", and an additional 40 percent consider the services as "good". 80 percent of citizens assesses the quality of medical services in public healthcare as good or very good, while in the same survey healthcare workers were graded as the best public workers amongst all public services in Croatia (Budak, 2014: 275-276). The conclusion can be drawn that total unidentified expenditures relating to compensation for damages do not significantly burden the Croatian Health Insurance Fund's budget, so therefore they are not recorded separately. It is clear that the Croatian healthcare system, contrary to those other analysed in this paper, are not burdened with significant costs stemming from compensation to patients. It is worth noting that there 
exists a certain awareness of the issue concerning insuring physicians against professional liability, and thereupon the issue of types of breaches against medical standards in providing services, which is supported by the elaborated research of the EHCI index in the segment referring to assessing the degree to which a physician can be can be subjected to liability might work as well.

Based on the above, we can conclude that Croatian legislation and medical practice are in conflict with with the practices of the other countries analyzed in this paper in view of the fact that, to date, Croatia has not experienced a significant occurrence of court litigations for damages which are the result of breaches to the medical standards of care. Moreover, relevant scientific research on this and statistical information relating to "medical damages" is completely lacking. This may well be explained by the fact that the public has not been particularly well-informed about medical malpractice except in drastic cases (e.g., the case of Maškarin). It would make sense logically that the Croatian public would assert fewer cases of medical malpractice given the general lack of knowledge of the problem. Furthermore, the issue of medical malpractice has not, as of yet, been collectively legitimised as an important topic, where the reason should be primarily sought in the fields of sociology, social anthropology and psychology. Maybe then we could be able to answer the question as why Croatians have not seen fit to date to assert a lot of claims against the medical profession. Thus, in Croatian society there has always been a general attitude of prevailing respect towards the medical profession as one which performs humanitarian work and which apparently does not belong in the commercial sphere or treated, for example, like mere artisans, such as plumbers, bricklayers or carpenters. In other words, medical professionals in Croatia have been placed on a higher plane than is the case with other workers. On the hypothetical scale of collective respect, attitudes towards physicians are ranked solidly in second place, immediately behind religious ministers.

The economic discourse relating to the analysed problem emphasises the economic effects of utilizing the legal system, and in particular tort liability for damages, as a method of both preventing the onset of harmful events in the first instance, that is to say, deterrence, as well as by compensating victims of medical malpractice for incurred damages. Economists agree that the tort claims system should be viewed as incentivising healthcare providers to continually improve the healthcare system in order to avoid expensive liability. The idea that a potential tortfeasor compensate the victim (i.e., the plaintiff), should have a preventive or deterrent effect (Cf. Schiemann, 1981, p. 185). In this way, moreover, the best modality in protecting patient rights is emphasized as potential injured parties and it influences preventing the occurrence of socalled victimization, because no one can dispute that preventing damage is also a way of protecting victims. This differentiation also contains the ex ante and ex post approach. Although the legal system is directed mainly towards ex post action, when there occurs a harmful event that requires seeking damages, economists approach the issue of compensation ex ante. In that sense, economic theory poses the question as to how an ex post approach can influence incentive so that it acts preventively pro futuro. 


\subsection{The General Framework of Tort Liability of Physicians in Croatian Legislation}

When considering harmful action as the basis for tort liability borne by physicians we can distinguish as to whether it involves a medical error caused by a medical procedure that is not in line with lex artis, i.e., medical treatment not performed according to required professional standards and professional skills on account of which the patient suffers harm; whether it involves medical treatment that the physician performed without proper patient consent, and during which the patient suffered harm in terms of deteriorated health; or simply a breach of rights against physical integrity.

Unlawful actions, which are a condition for the onset of a tort relationship, exists in cases when a legal norm is infringed upon and where the infringement requires ipso iure the seeking of damages which lies in a cause-and-effect relationship with unlawful behaviour. When considering the issue of tort liability for a physician, there is substantial literature that helps to define exactly what conduct establishes liability. Specifically, it becomes necessary to keep in mind the particular circumstances involved in performing such healthcare services, as well as the fact that medical treatment is inherently risky. Overall, medicine, contrary to other natural sciences, is not a static science. In that sense it must be stressed that not only are established and recognised rules relevant, but also partly recognised in medical science as a dynamic part of the medical standard. This dynamic dimension is always adapted to the altered status of medical science and practice, and without which there would be no progress in medicine. In tandem with the decision by the physician to implement this dynamic part of the medical standard the physician must additionally always take care to insure a provable assessment of risks and benefits for the patient.

Legal theory states that in determining the content of standards within the medical profession, it is not enough to only determine the established and recognized rules of the medical profession, but instead assess the actions of the healthcare worker in the specific circumstances from which it arises, namely that the only "common designation" for determining the existence of malpractice in medical treatments is a breach of due care (Petrić, 2005: 123). A breach of due care undoubtedly indicates the existence of fault as a subjective element of unlawfulness and the presumption of the existence of tort liability that is cumulatively required in most legal systems.

In Croatian legislation a healthcare worker performing a medical service must act with the care of a good professional, i.e. act with heightened care, according to the rules and customs of their profession (Para. 2 of the Physician Act, Official Gazette no. 121/03 and 117/08). Therefore, the law requires medical workers to act in accordance with the standards of a good, not average, professional. A breach of such imposed professional standards is defined as a harmful action characterized as unlawful in subjective terms, under the presumption of the onset of legally relevant damage. When performing medical treatment, it is explicitly required not only that the physician obey the rules of the healthcare profession, so that their actions do not jeopardize the life and health of the patient (Art. 124, Para. 3 of the Healthcare Protection Act, Official Gazette no. 150/08, 155/09, 71/10, 139/10, 22/11, 84/11, 154/11, 12/12, 35/12, 70/12, 
144/12), but also that they promote dignified and responsible professional behaviour by adhering to regulations, rules of the profession and the codes of medical ethics and deontology (Art. 2, Para. 2, Pt. 5 of the Physician Act, Official Gazette no. 121/03 and $117 / 08)$.

Tort liability for medical malpractice is founded on the principle of presumed guilt, meaning that the presumed tortfeasor must prove in litigation proceedings that they have obeyed all of the rules of the medical profession and that the damage did not occur due to negligence by the physician who carried out the disputed medical procedure:

\begin{abstract}
“...hospital is liable for mistakes by physicians based on the principle of presumed guilt, meaning that it must prove that it acted completely as prescribed by the rules of the medical profession, and that harm did not occur neither due to supposedly ordinary negligence by the physician who carried out the procedure. Moreover, what is decisively significant is also the circumstance as to whether the claimant was informed of the possible risks of fine needle aspiration which she underwent. The only consent that is valid is consent to the diagnostic procedure that the patient gave after being informed of possible risks associated with the respective procedure. Only in that case is there no tort liability by the hospital for incurred immaterial damages". (Constitutional Court of the Republic of Croatia, no. U-III-1062/2005 of 15 November 2007)
\end{abstract}

\title{
1.4 The Notion of Medical Malpractice
}

Medical malpractice is a term that originates from medicine and was formulated by the renowned German physician, pathologist Rudolf Virchow, at the end of the nineteenth century. Virchow coined the term malpractice by physicians (Kunstfehler der Arzte), a term which implies "a breach of generally-recognized rules in the medical profession due to lack of due care or caution". The syntagma of generallyaccepted rules within the medical profession covers the principles that are not subject to theoretical doubts, but rather represent axioms of natural science, and used the example of exceeding maximum medicinal doses which he later called absolute professional errors (Virchow, 1879). Legal literature also cites other definitions of medical malpractice.

Croatian legislation does not define the term medical malpractice; however, the content of the term can be determined negatively, by enumerating the obligations of physicians during a medical treatment undergone by a patient, and which are determined in laws and professional regulations. The term medical malpractice clearly indicates that it involves a mistake on the part of the physician in carrying out their professional medical treatment for the recipient of healthcare services. When defining the term medical malpractice, it is important to identify the fact that in the basis of the term medical malpractice, there clearly lies the actions of the physician that are contrary to the rules of the healthcare profession in general, as well as to the standards of modern medicine and practice based on its dynamic dimension, that is, acting 
contra legem artis. As stated in the previous section, established and recognised rules are relevant, but so too are the rules that are partly recognised in the medical science as a dynamic part of medical standard, which permanently adjust to the new achievements of medical science and practice and without which there would be no real medical progress. Nonetheless, the content of the term medical malpractice is not complete if reduced solely to the actions of the physician, contrary to the general rules of the healthcare profession, given that Croatian and comparative legal literature cites that the term medical malpractice also includes actions by a physician that are dissimilar to moral and ethical principles, plus modern medical standards.

Consequently, in order to create a definition within Croatian legislature, the term medical malpractice is best defined as the actions of the physician involving a medical procedure for a patient, contrary to the rules of the healthcare profession including its moral and ethical principles. In other words, it consists of actions taken by the physician that do not comply with verified standards of modern medical science in its dynamic dimension, which have resulted in jeopardising the patient's health and life, i.e. an infringement of the right of personality.

In line with the presented principal understanding, the term medical malpractice should include medical procedures for patients that are performed without patient consent, i.e., when it involves situations that we identify using the syntagma "arbitrary treatment". Namely, the described actions by the physician, despite the possibility of performing the medical treatment according to the rules of the medical profession, which can be designated per extensum by the term medical malpractice given that it undoubtedly involves cases when, due to the infringement of the rights of the patient to co-decide (informed consent), harm occurs in terms of infringement of the right to physical integrity, which is one of the protected patient's right of personality.

Based on the above, we can conclude that "arbitrary treatment" essentially represents a breach of the underlying ethical and moral principles of the medical professional, as well as the generally-accepted medical protocols contained in the definition of medical standards. This includes new methods and practices, which shape dynamic medical standards and consequently, are justifiably qualified under the term medical malpractice in extensor sensu.

In general, it is important to emphasize that the physician is obliged to apply generally-accepted rules of the medical science and profession, whereby the physician is, in accordance with the principle of professional autonomy in selecting the appropriate therapy or diagnostic methods, completely autonomous, but in cases of doubt, obliged to adhere to the principle of the "more sure" path. Medical malpractice occurs only if a method not recognised in medicine was selected by the physician. But in theory, there are various schools of thought surrounding a particular method, upon which the recommendation is then to rely on the generally-accepted practice (Kennedy, 1985: 137). 


\section{Distinguishing Medical Malpractice from Medical Treatment Complications}

\subsection{The Term Medical Complications and an Overview of Relevant Practice}

Standard practice and literature draw a distinction when it comes to the terms medical malpractice and medical complications during treatment. They both state that medical malpractice implies actions by the physician in a medical procedure for a patient which are performed contrary to the rules of the healthcare profession, along with its moral and ethical principles, i.e., actions by the physician that do not comply with verified standards in modern medical science, which have resulted in harming the patient's health, life or right of personality.

As opposed to medical malpractice, the term complications during medical treatment procedure implies an undesired result stemming from a medical procedure that occurred despite properly performing the procedure on time, and that was performed with the use of proper equipment and substances (medicines, chemical substances and the like), as well as subject to the optimal organization of healthcare services (Ćepulić, 2007).

In Croatian practice this can be referred to where the distinctive elements for differentiating in casu particulari ad curiam the terms medical complications from the legally relevant medical malpractice:

"With regard to the cited findings and the legal position of the audit court, the lower courts have correctly concluded that the presumptions referred to in provision of Art. 170. Para. 1 of the Obligatory Relations Act (Official Gazette nos. 53/91, 73/91, 3/94, $7 / 96$ and 112/99), which the second defendant would be obliged to compensate the plaintiff for damages which the plaintiff seeks in this remedy, for the reasons that the complications which the plaintiff suffered after the injury are caused solely by the type and degree of the injury, and manner of its affliction are not the consequence of inappropriate or medical malpractice by the physician second defendant. Therefore, the lower courts have properly concluded that there is no causal relationship between the occurred damage to the plaintiff and actions, i.e., negligence in medically treating the plaintiff, hence the view of the audit court is that the second defendant is not obliged to compensate the plaintiff for incurred damages." (Supreme Court of the Republic of Croatia, Rev 1221/01-2 of 20 January 2004).

In further defining the term medical complications, it is necessary to refer to the fact that legal practice differentiates complications that are the unwanted result of a medical procedure where the factual and medical cause is to be sought in the nature of the harm and the circumstances of it is occur in the absence of physician fault or error, from complications that are the undesired consequence of unprofessional medical care, standing in a causal relationship with legally-based damages which makes the medical practitioner civilly liable for the harm: 
"It is contestable in this phase of the proceedings as to whether damages that the plaintiff seeks from the defendant under has occurred on account of poor or inadequate, i.e., negligent or careless, actions by the physician - defendant, i.e., whether it occurred due to the physician's actions which were contrary to the rules of the medical profession. From the findings of the lower courts, the conclusion is: that the plaintiff, after having on 25 June 1996, received an injury to the third finger on the right hand, when the belt on the operating automobile motor caught that finger, sought help from the physiciandefendant; that the plaintiff underwent amputation of the last member of the injured finger, but also that he had a series of difficulties prior to that, but also after that because he suffered a number of surgical procedures followed by pain and difficulties; - that he was treated correctly by the physician - defendant, i.e., in accordance with the rules of the medical profession and that the consequences experienced by the plaintiff are not the result of inappropriate or erroneous medical treatment, but instead that the complications were caused solely due to the type and degree of injury, and the manner of it being afflicted. Considering the presenting findings and legal view of this audit court, the lower courts have correctly concluded that the presumptions referred to in the provision of Art. 170, Para. 1 of the Obligatory Relations Act (Official Gazette nos. 53/91, 73/91, 3/94, 7/96 and 112/99), according to which the defendant would be obliged to compensate the plaintiff for damages which the plaintiff seeks in this remedy have not been fulfilled. The reason being is that the complications that the plaintiff suffered after being injured were caused solely due to the type and degree of the injury, the manner in which it was afflicted, and not the consequence of inappropriate or erroneous medical treatment provided by the physician - defendant. This means that there is no causal relationship between the harm incurred by the plaintiff and actions, i.e., no negligence in the medical treatment received by the plaintiff, as the lower courts have correctly concluded, and it is the view of this audit court that the defendant under 2 is not obliged to compensate the plaintiff for incurred damages." (Supreme Court of the Republic of Croatia, Rev 1221/01-2 of 20 January 2004)

Medical complications arising from medical procedures represent in sensu strictori a harmful event occurring in a medical procedure resulting in the course of an illness and particular circumstances, without fault on the part of the medical personnel (Ćepulić, 2007). The latter decision by the Supreme Court of the Republic of Croatia considered the existence of tort liability based on the assertion that damage to a bladder occurred as a result of medical malpractice while conducting a surgical procedure on the uterus. In the specific case, to assess the question of tort liability, the decisive matter was to ascertain whether during the surgical procedure to remove the patient's womb and ovaries the actions were performed "as they should have been". Based on the findings and opinion of the medical expert witness, that after the contested surgical procedure in which the miomatosic womb and adnexa were removed from the patient, a so-called vesicovaginal fistula occured (route between the 
gall bladder and uterus), due to a complication of the stated surgical procedure, and not as "malpractice". The court concluded that the physician in the given circumstances acted as he should have and that there was no tort liability (Supreme Court of the Republic of Croatia, Rev 1217-2).

Legal literature cites that complications involve situations experienced when the recipient of healthcare services suffers undesired consequences to their health which would not have occurred due to a breach of the rules and methods, i.e., work-related standards in the healthcare profession and/or scientific knowledge of the physician. In other words, it does not involve medical malpractice or a mistake on the part of other healthcare workers, but instead an unavoidable, random incident or result occurring during the ordinary course of events (Crnić, 2009: 64).

On the other hand, medical court practice points out that the essential characteristic of medical complications is the further development of the original illness or onset of other pathological conditions based on the primary illness, given that complications can occasionally occur as a result of error. This is why medical reports by expert witnesses are used to determine which part of the harmful consequences are due to error and which are because of complications (Škavić \& Zečević, 2008: 29).

Attention is drawn to the particularly important judgment by the Supreme Court of the Republic of Croatia, which determined the essential components in defining the terms medical malpractice and complications:

\begin{abstract}
"Complications are circumstances that occur during medical treatment and which took place undoubtedly professionally and with the greatest possible care. They occur randomly, and despite planning they cannot be prevented. Medical malpractice is the deviation from professional standards of expert actions, care and diligence which may result in any kind of deterioration of health." (Škavić \& Zečević, 2008: 29)
\end{abstract}

In Croatian practice, the Supreme Court of the Republic of Croatia considered a tort lawsuit that was based on the assertion that damage to the right urethra represented iatrogenic damage caused by the physician's unprofessional actions. The defendant in the lawsuit, on the other hand, defended the suit on the basis that the damage involved an undesirable complication stemming from a surgical procedure which, considering the clinical condition of the patient, could not be attributed to medical malpractice. The court, having evaluated the evidence, relied on the findings and opinion of the expert witness who ascertained that there was no factual, linear relationship between the specific injury and contested surgical procedure.

"Namely, these expert witnesses, although in existing medical documentation damage to the right ureter is accepted as iatrogenic, (resulting from a surgical procedure) have determined thatbased on existing medical documentation, it is more likely that the right ureter was damaged due to an inflammatory process on account of which underwent necrotization, which also resulted in the removal of the right kidney, s ascertained in the opinion of the expert witness, damage to the 
plaintiff did not occur due to the negligence of the surgeon, which meant he was not at fault, since under the given circumstances he acted according to the rules of the profession. This opinion has also been asserted by Prim. Dr D. H. in his findings, which has also been evaluated by the lower courts, that damage to the right ureter is the result of the anatomy of the pelvic region. Furthermore, it he found that, due to the advancement of inflammatory changes in the surrounding tissue, organs and adhesions, of which can be deemed as a complication stemming from a surgical procedure under the given conditions, but could not be attributed to medical malpractice, either carelessness or negligence." (Supreme Court of the Republic of Croatia, Rev 1216/062 of 11 July 2007)

Further reference is made to the practice of the Croatian courts relating to a recent case which involved medical malpractice committed in providing medical treatment during birth. During such treatment medical complications occurred that could not have been avoided; however, in eliminating the harmful effects of the complication, the physician failed to act in an adequately professional manner and with the required degree of attention, leading to the detriment of the patient's health:

"On 6 July 2001, at the Clinical Hospital, the plaintiff underwent a caesarean section so as to give birth, the delivery was performed, whereupon complications occurred such that during the caesarean section the plaintiff's uterus was torn, which was then removed together with the ovaries, and during the removal of the uterus there occurred the 'stitching of the left ureter resulting in the creation of an urethrovaginal fistula; that the plaintiff after the surgical procedure due to the consequences of stitching the left ureter resulting in the creation of a urethrovaginal fistula, which occurred due to medical malpractice, experience fear, specifically a primary strong fear over three days, secondary fear of a strong intensity amounting to 15 days, and that she experienced 15 days of medium-intensity fear, and low-intensity fear over a duration of 171 days, until recovery on 1 July 2002; that the plaintiff suffered a mild to medium level of disfiguration; that the plaintiff due to received injuries experiences a 25 percent reduction in performing ordinary activities, and in the same percentage she will have to invest additional effort for the same endeavours."(Supreme Court of the Republic of Croatia, Rev 20/2009-2 of 05/01/2012).

In the context of Croatian practice attention is drawn to the case where the court ascertained whether shoulder dystocia in a new-born infant was the result of medical malpractice or whether it involved an ordinary, yet rare complication, which appears in only 0.2 to 0.6 percent of births.

"The procedure ascertained: that the first plaintiff, the minor D. D. born on 20 March 1994 at the Sisters of Mercy Clinical Hospital, Clinic for Women's Diseases and Maternity, and that the second plaintiff $B$. 
$D$. his mother, and the third plaintiff $S . D$. his father; that during the birth, the first plaintiff received injuries, specifically a compound fracture of the left humerus, paralysis of the right brachial plexus, compound fracture of the collarbone and damage to the upper arm nerve fibres, as a consequence of the procedure to free the wedged shoulder during birth, after delivery of the head which occurred when freeing the shoulder (collarbone fracture, damaging the upper arm nerve fibres), are possible and that they occur during the so called 'shoulder dystocia', where dystocia is a phenomenon that occurs after delivery of the baby's head, but the shoulder gets wedged or remains behind, where the phenomenon according to the opinion of the medical expert witness Prof Dr J. $\breve{S}$. specialist in court medicine and Prof Dr A. D. specialist in gynaecology and maternity (whose opinion is attached to sheet 75 of the case file) appears only in 0.2-0.6 percent of all deliveries, and that it has occurred before to the defendant in 0.25 percent of cases; that the delivery for the second plaintiff was conducted in accordance with current maternity practices, and that the described complications occurred due to the large weight of the child (4520 g), whose weight was the result of the excessive weight of the second plaintiff during pregnancy, and which is the result of its excessive increase in body weight, - that despite all that has been said, the second plaintiff as a healthy woman with a normal physique, was able to give birth to a child of larger weight without delivery via the so called 'caesarean section'; - that during supervision of the final part of the pregnancy and performing the delivery for the second plaintiff, there were no actions or omissions that were the cause of the first plaintiff's injuries; - that the hospital and defendant acted according to the rules of the profession, on account of which they are not liable for damages." (Supreme Court of the Republic of Croatia Rev 39/2006-2 of 14 February 2006)

Comparative court practice seldom encounters doubt as to whether in a particular case that the damage claimed stems from the usual complications related to performing certain medical procedures as opposed to negligence due to the physician's actions. Hence, in the matter of Smith v. National Health Service Litigation Authority, the court ascertained that the harm inflicted on the patient during the medical procedure did not represent a usual surgical risk, but instead involved medical malpractice. Namely, in this case, the claim for damages resulted from performing a radical hysterectomy and the associated removal of potential cancerogenic lymph nodes. During the operation, the patient's right obturator nerve was severed, which later led to the perforation of her left external iliac vein. As a result of these injuries occurring due to unprofessional actions by the surgeon physician, the patient suffered from a life-changing disability. Although the defendant asserted that the occurred injury represented a normal risk in the operation, the court determined that it involved unprofessional actions by the surgeon physician and that the prerequisites for tort liability were met (Cf. Smith v. National Health Service Litigation Authority, 2001). 
The next typical cases from Croatian court practice indicate the importance of professional cooperation with medical expert witnesses who consider the relevant factual issues. Hence, the court, in evaluating the findings and opinion of the expert witness, ascertained that increased intraocular pressure suffered by the plaintiff is not an absolute contraindication of surgery that was performed. Surgery of the cataract had to take place, as it was the fundamental cause of increased intraocular pressure, hence the actions of the surgeon physician in that specific case complied with the rules of the profession. Until this point in time the specific cause of expulsive massive bleeding cannot be known for sure, although exceptionally rare, cannot be foreseen, whereas the surgeon, when the same complication occured, has no opportunity whatsoever of saving sight function or the anatomic shape of the eye (Supreme Court of the Republic of Croatia, Rev 397/06-2 of 28 June 2006).

The court determined in simili casu on the basis of the findings and opinion of the physician expert witnesses (who were in full agreement on the matter) that the physician who performed the procedure acted lege artis and with all due care. The harmful consequences suffered by the plaintiff were not in a causal relationship to any mistake or omission by the surgeon, but instead were to be attributed to the usual risks associated with this type of procedure, especially due to the claimant's medical condition. The patient had a very thin uterus wall, considering that she had given birth twice before and prior to the procedure she had her fallopian tube removed due to a pregnancy, and the molar pregnancy of 18 weeks presented a very high risk for procedures. In such cases when pregnancies exceed 10 weeks, there is a 100 percent heightened risk, hence it is possible that due to the thin and fragile uterus wall and regardless of preparation (in the specific case it was prepared prior to the procedure in the usual manner - by administering stimulators for constricting the uterus) a perforation of the uterus occurred and a thus the plaintiff experienced a complication. As has been ascertained, a proper diagnosis was established for the plaintiff, that the generally-accepted medical procedure for treatment was timely prescribed, the proper preoperative preparation and analgesia was conducted, the procedure was performed at a healthcare institution that was certified for such procedures in the usual manner by a specialist physician certified for such procedures and that the damage that occurred to the plaintiff could not be attributed to negligence on the part of the surgeon-defendant, not because he acted in line with the rules of the profession, but because a complication occurred due to the surgical procedure under the given conditions (Supreme Court of the Republic of Croatia, Rev 985/07-2 of 28 November 2007). In the following case, the court established that damage to the right ureter was the result of the anatomy of the pelvic region, and due to the advancement of inflammatory changes in the surrounding tissue, organs and adhesions. This could be deemed as a complication stemming from a surgical procedure under the given conditions, but could not be attributed to medical malpractice, either carelessness or negligence (Supreme Court of the Republic of Croatia, Rev 1216/06-2 of 11 July 2007). 


\subsection{Criteria for Differentiating Medical Malpractice from Medical Complications}

Regarding relevant court practice and legal literature, it is important to differentiate the term medical malpractice from the term medical complications during medical treatment. As elaborated above, medical malpractice implies the actions of a physician relating to a medical procedure on a patient, which is performed contrary to the rules of the profession and its moral and ethical principles, i.e. actions by the physician that do not comply with the verified standards of modern medical science, which results in an infringement to the patient's health, life and right of personality.

Contrary to the term medical malpractice, the term complications in medical treatments (medical complications) implies the undesired result of a medical procedure that occurs despite the procedure being properly performed and in a timely manner. Also included in the definition is the use of proper equipment and means (medicines, chemical substances and the like), along with the optimal organization of work (Ćepulić, 2007). The technical term complication includes those unexpected and unfavourable occurrences that are a consequence of an unforeseen course of an illness, injury or condition of a patient despite all undertaken lege artis medical procedures, proper equipment, medical devices and medical substances and appropriate organisation of healthcare services (Domljan, 2006).

Comprehensively differentiating the term medical malpractice from the term medical complications is found in comparative practice, which defines medical complications as circumstances occurring during medical treatment that are performed professionally with the utmost care and occurred randomly, despite preventative efforts. In juxtaposition, medical malpractice represents a deviation from professional standards associated with professional work, care and attention that may lead to any kind of deterioration of health (Supreme Court of the Republic of Croatia, Rev 1216/06-2 of 11 July 2007). Furthermore, qualifying medical complications depends on medical treatment administered professionally, without negligence. For example, actions contrary to the rules of the profession where the actual complications that occurred following the performed treatment was not the result of carelessness, negligence or ignorance, meaning that there is no fault on the part of the physician. For the purpose of contextualization, reference is made to a recent court judgment from the Croatian courts:

"Namely, from the findings and opinion of the medical expert witness, in regard to actions by the surgeon physician, the conclusion is that there was no negligence, i.e. no medical malpractice during surgery on the patient. According to the findings of the lower courts, the conclusion is that it involves a standard medical operation, though invasive in nature, which in essence includes possible complications, as is with any other surgical procedure, and which was performed on the plaintiff in line with the rules of the profession, hence the presumptions for application of Art. 170 of the Obligatory Relations Act (Official Gazette nos. 53/91, 73/91, 111/93, 3/94, 7/96, 91/96, 112/99 and 88/01) in relation to provision of Art. 154, Para. 1 of the Obligatory Relations 
Act have not been fulfilled, hence the lawsuit is validly rejected." (Supreme Court of the Republic of Croatia Rev - x 56/2011-2 of 31 August 2011).

A case (casus) is defined as an event that cannot attribute fault to anyone, which cannot be foreseen, even though it could have been avoided had it been foreseeable. According to the well-known definition, a case is an event which, had we been able to foresee it, we would have prevented it, as opposed to a force majeure event where, had we been able to foresee it, we would not have been able to prevent it (Klarić \& Vedriš, 2003: 547-572). A case is a certain event that excludes liability of the tortfeasor in regard to subjective liability, or liability based on the fault principle, and in accordance to the principle of casus a nemmine praestatur. ${ }^{1}$

It is important to point out that when a specific case involves the onset of medical complications, a fact of randomness (random event), medical malpractice and causality are excluded. All medical procedures pose a certain risk, which according to current medical science is not possible to foresee, while a patient consenting to a medical procedure assumes the risk in accordance with the principle casus sentit dominus. $^{2}$ Damage that occurs within the patient's sphere of health due to the onset of a random event following a medical procedure is called medical complications. Although complications cannot be foreseen, they can be expressed statistically, even though they would not represent random damage. For instance, the occurrence of a fatal event as a consequence of anaesthesia has a probability of 1:10,000, whereas for elderly people (older than 70 years), pulmonary complications occur in 5 to 10 percent of cases as a consequence of surgical procedures (Flis, 2008: 235).

Furthermore, Croatian practice refers to an illustrative verdict founded on the rules of subjective liability for medical malpractice, where the court ascertained that the hospital was liable for damages that occurred due to an infection which could not be considered an ordinary surgical risk. The court's view was that infections are considered to be ordinary risks in situations where said infections, could not be remedied using medical methods within a certain reasonable period and provided the assessment that the infection the plaintiff sustained most certainly did not arise from the ordinary surgical risk, because the infection significantly destroyed the plaintiff's health. Following the leg operation, the plaintiff underwent another nine surgical procedures. Even though nearly five years had passed since the operation leading to the court's decision, the patient still carries the un-remedied infection, his leg six centimetres shorter and stiff. According to an assessment by the court, such an infection, which is most often caused by inadequately sterile hospital conditions, was not considered an ordinary surgical risk (County Court in Zagreb, Gž-1938/99 of 14 March 2000):

„, The hospital is liable according to the principle of fault for the onset of the infection which cannot be considered an ordinary surgical risk.

\footnotetext{
${ }^{1}$ Lat. casus a nemine praestatur - no one is at fault for an accident.

${ }^{2}$ Lat. casus sentit dominus - the accident is felt by the owner, i.e., accidental destruction of a thing (accidental damage) is borne by the owner.
} 
The medical report by the expert witness ascertained that the plaintiff had a closed fracture of the leg and that the infection, called methicillinresistant staphylococcus (hereinafter: MRS), has its origins in surgical procedures, due to inadequately sterile conditions under which the surgical procedure was performed. It was also ascertained that the infection is of a hospital origin and that the infection did not occur due to a cause outside of the hospital. These facts are not disputed by the accused hospital, but it negates its liability and asserts that the origin of the infection during the surgical procedure is an ordinary surgical risk and that the hospital in such cases is not liable towards the plaintiff (patient) for damages. Such defensive assertions by the accused hospital are not founded. The proper conclusion by the first-instance court is that the respective infection due to MRS bacteria is not an ordinary surgical risk, which has been ascertained by the expert witness's report. This based on the fact that ordinary risk is considered to be those infections that can be remedied using medical methods within a certain reasonable period. The infection received by the plaintiff most certainly is not classified as an ordinary surgical risk, because the infection which the plaintiff got most certainly does not belong to ordinary surgical risk, because the infection significantly destroyed the plaintiff's health, on account of which the plaintiff following the leg operation underwent another nine surgical procedures and that the plaintiff, though almost five years had passed since the operation leading to the court's decision, still carries the unremedied infection, his leg is six centimetres shorter and stiff. The outcome of the infection still remains unclear, despite years of medical treatment. The hospital erroneously deemed that the patient had consented to the surgical risk by signing the surgical consent form, because at that time the plaintiff was not aware of the possibility of an infection as he had received. The signature of the patient does not exempt the accused hospital from liability for the occurred damage to the plaintiff, along with the deterioration of their health. It is certain that such an infection, which is most often caused due to inadequately sterile conditions in a hospital, cannot be deemed an ordinary surgical risk, hence the defendant is liable for damages pursuant to Art. 154, Para. 1 of the Obligatory Relations Act (1991)."

As could be seen, different causes can be distinguished between medical malpractice and medical complications. Accordingly, medical malpractice represents in esse a deviation from professional standards associated with professional work, care and attention, which as a consequence may deteriorate health and/or infringe the right of personality. On the other hand, the term complication implies the onset of health difficulties, which may occur during medical treatment that had been performed professionally and flawlessly, and with utmost care. Despite being foreseeable, they occur randomly and are not preventable (Supreme Court of the Republic of Slovenia, II Ips 385/2006 of 21 November 2008).

Given that complications in medical treatment procedures are deemed equivalent to 
random events, it is necessary to consult relevant court decisions that detail such legal cases. The following decision from Croatian practice defines the content of the legal institution of a case in regard to tort liability for medical malpractice. It states that the term case, as a legal preposition for exempting from liability for damages based on the culpa principle implies an event that occurs within the scope of someone's job, and has more strength than the strength of the responsible person whose actions can prevent the onset of a harmful event:

“...the perceived confusion and existence of hallucinations are the facts on account of which a person in that state was able to be controlled by the defendant, and which he had failed to do, but allowed to chance that the harmful event happen or that it not happen, whereas the defendant in the appeal unfoundedly asserts that it was an 'unfortunate event' which exempts him from liability for damages. Accordingly, the opinion of the medical expert witness concerning the matter remains irrelevant, because contrary to the defence's assertions, the assessment of the existence of a case as pertaining to legally relevant facts is a legal issue and not a medical issue, according to which the court should seek and take into account the opinion of the medical expert witness is regard to the provision referred to in Art. 250 of the Litigation Proceedings Act. A case (casus) is as the basis for exemption from causal liability for damages (Art. 177, Para. 1 of the Obligatory Relations Act (Official Gazette no. 53/91, 73/91, 3/94, 7/96, 91/96, 112/99 and 88/01 hereinafter: ORA) Given that in this case the conducting of appropriate measures covering supervision and care of the plaintiff could have prevented that she perform actions on account of which a harmful event occurred, the first-instance court has correctly assessed the existence of the defendant's liability for damages, whereas the defendant's assertions are unfounded that damage occurred on account of the case, the occurrence of which exempts the defendant of liability for compensation of damages, hence in relation to liability, the defendant's appeal is found to be unjustified." (County Court in Bjelovar, Gž2153/08-2 of 19 February 2009)

Finally, it is important to highlight the problem associated with the potential application of objective liability in the domain of medical practice. Specifically, although rules of subjective liability apply to cases of medical malpractice, in legal theory and judicial practice, sometimes certain uncommon points of views are noticeable, which indicate that when complications exceed the limits of what is acceptable, (the usual risks) the healthcare service provider becomes liable and the situation enters the sphere of liability according to the principles of objective liability, most often as a form of liability stemming from dangerous jobs. The emphasis is placed on the perception that, in the event of exceeding the limits of ordinary medical risk or due to complications that have occurred during medical treatment, there is justification to consider the liability of the healthcare service provider based on the principle of objective (causal) liability (Crnić, 2009: 66-67). 
It is important to notice that this is a 'slippery terrain', because as some authors have stressed, an introduction of objective liability in such cases may lead to an increase in liability of medical professionals. This could lead to fewer medical professionals willing to take risks, and suboptimal medical care could be provided to patients. Although, the objective liability in medicine is very disputable in theory and rare in practice, some of the court decisions head off in this direction, especially in the case of damage caused by "dangerous" medical devices, instruments and procedures.

\subsection{Concluding Notes}

Croatian legislation does not define the explicit terms associated with medical complications and medical malpractice, and their content is indirectly determined by court practice primarily. On the other hand, civil law determines the institute of force majeure (vis maior) and case (casus) as the reason for excluding tort liability. Every medical procedure carries a certain risk, and based on current medical science cannot be foreseen, whereas a patient giving consent to a medical procedure assumes the risk, in accordance with the principle casus sentit dominus. Harm that appears in the patient's sphere of health due to the onset of an accidental event which conforms to the realization of a medical risk is called a medical complication. Even though a complication cannot be initially foreseen upfront, as it would not then represent accidental harm, nonetheless it is possible to express it statistically.

In conclusion, it is important to differentiate the terms medical malpractice and medical complications, where in both terms a harmful event occurs that can jeopardise the patient's health or life due to the outcome of medical treatment. However, compared to complications during a medical treatment procedure which occur per accidens, despite the professional actions taken by the physician and in line with rules of the healthcare profession and accepted medical standards, among other things, the fundamental content of medical malpractice comprises in actions that are contra legem artis.

\section{Typical Cases from Croatian Court Practice (case study)}

\subsection{Supreme Court of the Republic of Croatia, Rev 265/12-2 of 28 February 2012}

\subsubsection{Fact Pattern}

The proceedings before the lower courts ascertained that the plaintiff was urgently admitted to hospital, was diagnosed with a rare illness described as thrombosis of the brain (dural) sinuses and increased intracranial pressure. Further, that all the adequate and intensive medication measures were administered during medical treatment, which did not include surgery and that a neurosurgeon did not participate in the medical treatment. Upon that, after the medical procedure, the plaintiff witnessed a deterioration of vision which halted the procedure, and that the loss of vision by the plaintiff was not the consequence of inadequate medical treatment, but instead thrombosis of the brain sinuses. Neurosurgical intervention (fluid drainage) in the early phases of the illness might have helped with the loss of vision, and that the 
treatment of thrombosis of the brain sinuses relies above all else on medical treatment. The absence of fluid drainage in the initial phase was not a professional mistake, but a decision meant to produce a better outcome for the patient, meaning that the surgical performed fluid drainage meant symptomatic and not causal medical treatment, and hence it was not possible to assert with certainty whether the vision would deteriorate despite the fluid drainage.

\subsubsection{Subject of Dispute and Course of the Proceedings}

The subject of the dispute is the motion by the plaintiff asking for compensation of damages related to the harm inflicted on the plaintiff's health, occurring as a consequence of untimely registering of health difficulties experienced by the plaintiff and the provision of inadequate medical assistance. Based on the medical report by the expert witness and factual findings, the lower courts concluded that the physicians had timely diagnosed the plaintiff with the illness and applied measures that they assessed would provide the best outcome in medically treating the patient.

\subsubsection{The Court's Assessment}

The audit court established that the lower courts were correct to reject the lawsuit claim deeming that there was no liability on the part of the defendant for damages in regard to Art. 154. Para. 1 of the Obligatory Relations Act (Official Gazette nos. 53/91, 73/91, 111/93, 3/94, 7/96, 91/96, 112/99 and 88/01).

Namely, pursuant to the provisions of Art. 154, Para. 1 of the ORA, the person who causes damage to another person is obliged to compensate for it if there is no proof that the damage occurred without the fault of the former. Accordingly, stemming from the fact that the defendant in the specific case is liable based on the fault principle, and that when providing medical treatment to the plaintiff there was no negligence and irregularity, i.e., actions contrary to the rules of the profession and that the current health condition of the plaintiff (sight impairment) had not occurred due to the manner of medical treatment by the defendant, the lower courts have provided a proper assessment that the plaintiff has failed to prove the existence of a cause-effect relationship between the manner of treatment provided to the plaintiff by the defendant, and the onset of plaintiff's health condition, which was reflected in a degree of sight impairment, on account of which the claim was rejected. The court accepted the entire assessment of the lower courts, because the same arises from the determined and decisive facts. Namely, based on the findings and opinion of the expert witnesses, in regard to the actions of the defendant, the conclusion was that there was no negligence, i.e. medical malpractice in treating the plaintiff, given that the surgical procedure for thrombosis of the brain (dural) sinuses is not essential, and that such a procedure is decided on an individual basis whilst taking into account all the circumstances of the specific case.

Whether additional medical treatment using a fluid drainage would have helped to reduce vision impairment for the plaintiff cannot be ascertained with certainty. According to the findings of the lower courts, the conclusion is that only on the basis of probability can one say whether undertaking surgical treatment would have 
prevented greater vision impairment for the plaintiff or that the plaintiff would not suffer vision impairment at all, hence the correct conclusion by the lower courts that the existence of a cause-effect relationship had not been proven, between the manner in treating the plaintiff and the onset of damage or consequences of vision impairment on account of which presumptions have not been fulfilled for the application of the provision of Art. 170, in relation to the provision of Art. 154, Para. 1 of the ORA, hence the claim was justifiably rejected.

\subsection{Supreme Court of the Republic of Croatia Rev - x 56/2011-2 of 31 August 2011}

\subsubsection{Fact Pattern}

The proceedings before the lower courts ascertained that the plaintiff suffered from otosclerosis, of which a surgical procedure was performed on the plaintiff's left middle ear on three separate occasions, that it involved an ordinary, routine procedure, performed under ideal conditions, using a standard procedure and performed according to the rules of the medical profession. The plaintiff suffered from a complication from the performed procedure, getting a virus, which led to the plaintiff experiencing a deterioration of her health, which resulted in paresis (weakness partial palsy) of the left facial nerve, which was a complication, and therefore does not represent medical malpractice.

\subsubsection{Subject of Dispute and Course of the Proceedings}

The subject of the dispute lays with the plaintiff's motion requesting compensation for damages related to the harm inflicted on their health, which originated from a surgical procedure. Based on the medical report from the expert witness, the lower courts concluded that there was no negligence during the surgical procedure by the surgeon defendant; rather the complication happened to arise after the surgical procedure in spite of the surgery being performed according to the rules of the profession.

\subsubsection{The Court's Assessment}

The audit court established that the lower courts were correct to reject the claim deeming that there was no liability on the part of the defendant for damages, stating Art. 154. Para. 1 of the Obligatory Relations Act (Official Gazette nos. 53/91, 73/91, 111/93, 3/94, 7/96, 91/96, 112/99 and 88/01). Namely, pursuant to the provisions of Art. 154, Para. 1 of the ORA, the person that causes damage to another is obliged to compensate for any harm caused if there is no proof that the damage occurred without the fault of the former party. Accordingly, stemming from the fact that the defendants in the specific case are liable based on the fault principle, and that when providing medical treatment to the first plaintiff there was no negligence or irregularity, i.e., actions contrary to the rules of the profession and that complications that occurred after the surgical procedure were not a result of carelessness, negligence of ignorance, but rather an omission by the defendant's worker. 
The Supreme Court of Croatia has fully accepted the conclusion by the lower courts, given that it stems from the ascertained and decisive facts. Namely, based on the findings and opinion of the medical expert witness, in relation to the actions of the surgeon physician, there was no negligence or medical malpractice that occurred during the operation on the plaintiff. According to the findings of the lower courts, the conclusion involved a standard medical operation, yet invasive, which in essence included the possibility of complications, as does any other surgical procedure, which was performed on the plaintiff according to the general rules of the profession, hence the presumptions have not been fulfilled when looking referring to Art. 170 of the ORA in relation to the provision of Art. 154. Para. 1 of the ORA. Because of the abovementioned, the claim was correctly rejected.

\subsection{Supreme Court of the Republic of Croatia, Rev 876/06-2 of 10 January 2007}

\subsubsection{Fact Pattern}

A surgical procedure for zapping kidney stones was performed on patient Z. B. under full anaesthesia using ultrasound vibrations. It was a routine operation (lasting 1 to $1.3 \mathrm{hrs}$ ) and performed in the x-ray room, not in the operation room, which was equipped with a recovery room, also used for verifying vital functions early in the postoperative period. The actual operation and anaesthesia went well without any complications. After the operation, the medical nurse, assisted by a cleaning lady, transported the patient from the x-ray room to a lower floor. The room did not have the necessary instruments and devices for quick and effective reanimation. Whilst transferring the patient from the transport chair to the bed, the medical nurse noticed a bluish colour on the skin and fingernails, which is a sign of difficult breathing, which is why she used a balloon breathing bag over a mask to try and alleviate the patient's struggle to breath - but had no success. A telephone call was made to the on-duty anaesthesiologist in the intensive care unit. The anaesthesiologist was about 60 meters from the urological ward, and had to pass through three doors, one of which had to be unlocked to get to the patient, to try and reanimate him. The patient was no longer breathing spontaneously, and had a weak heart reaction, which is why urgent intubation was started and external massaging of the heart. Then he was given intravenous adrenaline after which heart activity was noticed, leading to normal skin colour. After that, the patient was transferred to the intensive care unit for further treatment. He survived, but suffered serious and irreparable brain damage (persistent vegetative state).

\subsubsection{Subject of Dispute and Course of the Proceedings}

The subject of the dispute is the plaintiff's request for compensation of non-material and material damages (funeral and other costs) due to the death of a close person (the plaintiff here is a relative of the person above named $\mathrm{Z} \mathrm{B}$ ). The first-instance court decision rejected the lawsuit request by the plaintiff for payment of damages. The second-instance court rejected the plaintiff's appeal as unfounded and confirmed in full the decision of the first-instance court. The plaintiffs announced a revision against that court decision. The Supreme Court of the Republic of Croatia accepted the 
revision as founded and terminated both court decision returning the case for judgement once again.

In the revision phase of the proceedings, the defendant's liability is contested, i.e., as to whether is it due to the negligence of the medical personnel in postoperative treatment of the now deceased $\mathrm{Z} \mathrm{B}$. that the cardiorespiratory arrest (heart failure and cessation of breathing) occurred, and as a consequence serious brain damage due to insufficient oxygen (cerebral atrophy), which could have been prevented had the hospital staff reacted quicker.

\subsubsection{The Court's Assessment}

The patient remained alive, but with serious and irreparable brain damage. Normally, patients who had had kidney stones zapped are taken from the x-ray room to the recovery room, and are to be accompanied by an anaesthetist technician who then calls upon an anaesthesiologist physician if necessary, who is usually in close proximity. The patient was 23 years old during the operation and had no health problems. Given that the legal view by the lower courts could not be accepted as regular, the auditors had justifiably defeated it in the audit. The assessment as to whether a causal relationship existed or not is a legal question concerning that the courts were to decide, not an expert witness.

It so happens that in the specific case (according to the statement of the medical nurse) the patient was transported to the urological ward while he had not yet woken up, and that timely reanimation was absent due to a lack of close monitoring, nor the possibility of urgent intervention by qualified medical personnel. Namely, the absence of medical malpractice and a causal relationship existed when the harmful consequence could not have been overcome, despite acting with the required care in accordance with medical standards, which in this specific case was absent. The defendant, according to the understanding of the Supreme Court, could not exculpate herself by stating that the health problems of $Z$. B. should be accepted as an anaesthetic risk, whereas in the given circumstances actions were not taken as they should have been according to the Art. 170 and 171 of Obligatory Relations Act (Official Gazette no. 53/91); whereas Croatian tort law attributes fault to the tortfeasor (Art. 154 of ORA). Namely, the question is posed as to whether in this specific case the cardiorespiratory arrest could have been prevented in the postoperative phase, and when it occurred - noticing it on time and quick reanimation in order to eliminate fatal consequences - ischemic brain damage, and whether the situation led to the death of the patient after six years, given that, as has been confirmed, that $\mathrm{Z}$. B. was 23 years old and otherwise healthy. It was a routine surgical procedure and the operation and anaesthesia went well, i.e. it has not been ascertained that it involved any kind of physical specifics and the like, that according to existing medical science could not have been foreseen - in other words that it involved a fateful outcome of the illness.

The court specified that pursuant to Art. 8 of the Litigation Proceedings Act (Official Gazette nos. 53/91, 91/92, 112/99, 129/00, 88/01 and 117/03) it has a duty to assess all provided evidence, including the findings of the expert witness (as one of the evidences), in their totality, and determine the cause-effect relationship for the specific 
case, evaluating all the determined circumstances and facts, but not to accept the general ascertainment from the expert witness findings that it involves an exceptionally rare, but known complication. This means that even if timely intervention had taken place, it should not have necessarily led to a more favourable reanimation (therefore, it is uncertain). Namely, in such cases when a certain doubt exists as to the causality, given that sometimes causality is very difficult and almost impossible to ascertain, the decision on the causal relationship can be based solely on the adequately high level of probability of its existence.

Given that the courts erroneously applied material law according to Art. 395, Para. 2 of Litigation Proceedings Act (Official Gazette nos. 53/91, 91/92, 112/99, 129/00, $88 / 01$ and 117/03), both of the court decisions were terminated by the Supreme Court, and in repeated proceedings the circumstances and facts will be ascertained and assessed in relation to the cause of the death of the deceased, given the modified lawsuit (Supreme Court of the Republic of Croatia, Rev 876/06-2 of 10 January 2007).

\section{Legislation}

Healthcare Protection Act, Official Gazette no. 150/08, 155/09, 71/10, 139/10, 22/11, 84/11, $154 / 11,12 / 12,35 / 12,70 / 12$ and 144/12.

Litigation Proceedings Act (Official Gazette nos. 53/91, 91/92, 112/99, 129/00, 88/01 and 117/03).

Obligatory Relations Act, Official Gazette nos. 53/91, 73/91, 111/93, 3/94, 7/96, 91/96, 112/99 and $88 / 01$.

Physicians Act, Official Gazette no. 121/03 and 117/08.

\section{Overview of court practice}

Republic of Croatia:

1. Constitutional Court of the Republic of Croatia, no. U-III-1062/2005 of 15 November 2007

2. Supreme Court of the Republic of Croatia, Rev 20/2009-2 of 05/10/2012

3. Supreme Court of the Republic of Croatia, Rev 39/2006-2 of 14 February 2006

4. Supreme Court of the Republic of Croatia, Rev 265/12-2 of 28 February 2012

5. Supreme Court of the Republic of Croatia, Rev 397/06-2 of 28 June 2006

6. Supreme Court of the Republic of Croatia, Rev 876/06-2 of 10 January 2007

7. Supreme Court of the Republic of Croatia, Rev 985/07-2 of 28 November 2007

8. Supreme Court of the Republic of Croatia, Rev 1217-2

9. Supreme Court of the Republic of Croatia, Rev 1216/06-2 of 11 July 2007

10. Supreme Court of the Republic of Croatia, Rev 1221/01-2 of 20 January 2004

11. Supreme Court of the Republic of Croatia, Rev - x 56/2011-2 of 31 August 2011

12. County Court in Bjelovar, Gž-2153/08-2 of 19 February 2009

13. County Court in Zagreb, Gž-1938/99 of 14 March 2000

Slovenia:

1. Supreme Court of the Republic of Slovenia, II Ips 385/2006 of 21 November 2008 
United Kingdom

1. Smith v. National Health Service Litigation Authority [2001] Lloyd's Rep Med 90

\section{References}

Arlen, J. (2010) Contracting over Liability: Medical Malpractice and the Cost of Choice, University of Pennsylvania Law Review, 158(4), pp. 927-1023.

Arlen, J. (2013) Economic Analysis of Medical Malpractice Liability and its Reform. New York University Public Law and Legal Theory Working Papers, Paper 398, retrieved from: $\mathrm{http} / / /$ citeseerx.ist.psu.edu/viewdoc/download?doi=10.1.1.828.1313\&rep=rep1\&type= pdf (January 05, 2019).

Budak, J. (2014) Ocjena pacijenata o kvaliteti rada zdravstvenog osoblja, In: Vehovec, M. (ed.) O zdravstvu iz ekonomske perspektive (Zagreb: Ekonomski institut).

Crnić, I. (2009) Odgovornost liječnika za štetu (Zagreb: Organizator).

Ćepulić, E. (2007) Profesionalna odgovornost liječnika i skandinavski model osiguranja liječnika (nofault compensation system), lecture presented at Simpozij Profesionalna odgovornost liječnika (Hrvatska liječnička komora. Zagreb).

Domljan, Z. (2006) Komplikacija ili propust u dijagnostici i liječenju, Liječničke novine, 54.

European comission (2006) Medical errors: Special Eurobarometer 241/64.1 and 64.3-TNS: opinion and social, medical error, retrieved from: http://ec.europa.eu/commfrontoffice/publicopinion/archives/ebs/ebs_241_en.pdf (March 20, 2019)

Fattorini, P., Peretti, A., Bergamini, P. \& Valentini, R. (2007) Casistica ortopedica dell' osservatorio GISDI, Medical malpractice daily. Supplemento di Medicina Legale Quaderni Camerti, reg. Trib. Di Camerino.

Ferrara, S. D., Boscolo-Berto., R. \& Viel, G. (eds.) (2013) Malpractice and Medical Liability (Berlin: Springer).

Flis, V. (2008) Medicinska napaka, In: Reberšek Gorišek, J., Rijavec, V., Flis, V., Planinšec, V., Kraljić, S., Peršuh, M., Gadžijev, E., Rudolf, C. \& Repas, M. (eds.) Medicina in pravo - sodobne teme (Maribor: Pravna fakulteta), pp. 233-244

Grubb, A. (ed.) (2004) Principles of medical law (2nd ed.) (Oxford: Oxford University Press).

Kennedy I. (1985) England, In: Deutsch, E. \& Schreiber, H.(eds.) Medical Responsibility in Western Europe: Research Study of the European Science Foundation (Berlin: Springer).

Klarić, P., \& Vedriš, M. (2003) Građansko pravo (7. izmijenjeno i dopunjeno izd.) (Zagreb: Narodne novine).

Lewis, M. (2012) Medical malpractice costs continue to climb, Medical Economics, 11. Jan. 2012, retrieved from: https://www.medicaleconomics.com/articles/medicalmalpractice-costs-continue-climb\%20 (January 05, 2019).

Petrić, S. (2005) Građanskopravna odgovornost zdravstvenih djelatnika, Zbornik Pravnog fakulteta Sveučilišta u Rijeci, 26(1), pp. 81-145.

Schiemann, G. (1981) Argumente und Prinzipien bei der Fortbildung des Schadensrechts (München: Beck).

Škavić, J. \& Zečević, D. (2008) Komplikacija i greška - sudskomedicinski pristup. In :Barbić, J. (ed.), Građanskopravna odgovornost u medicini: okrugli stol održan 27. 2. 2008. u HAZU (Zagreb: Hrvatska akademija znanosti i umjetnosti).

Tarantino, U., Giai Via, A., Macri, E., Eramo, A., Marino, V. \& Marsella, L. T. (2013) Profesional Liability in Orthopaedics and Traumatology in Italy, Clinical Orthopaedics and Related Research, 471(10), pp. 3349-3357, doi: 10.1007/s11999-013-3165-6.

Traina, F. (2009) Medical Malpractice: the experience in Italy, Clinical Orthopaedics and Related Research, 467(2), pp. 434-442, doi: 10.1007/s11999-008-0582-z. 
Virchow, R. (1879) Gesammelte Abhandlungen aus dem Gebiete der öffentlichen Medizin und Seuchenlehre (Vols. 1-2) (Berlin: Hirschwald). 
